Article

\title{
Energy Justice as Part of the Acceptance of Wind Energy: An Analysis of Limburg in The Netherlands
}

\author{
Nikki Kluskens *, Véronique Vasseur and Rowan Benning
}

International Centre for Integrated Assessment and Sustainable Development (ICIS), Maastricht University, 6200 MD Maastricht, The Netherlands; veronique.vasseur@maastrichtuniversity.nl (V.V.); rowanbenning@gmail.com (R.B.)

* Correspondence: n.kluskens@student.maastrichtuniversity.nl; Tel.: +31-657584916

Received: 30 September 2019; Accepted: 13 November 2019; Published: 18 November 2019

check for updates

\begin{abstract}
Policy documents in Limburg stress the importance of participation and distribution of benefits in wind energy projects, but it is not clear which modes of participation and distribution of benefits are most just, both in terms of perceived justice, and in terms of justice principles. Research shows that considering justice in renewable energy transitions increases the level of acceptance. This study aims to provide insight in what modes of participation and distribution are perceived as most just and likely to create local acceptance of wind parks. The most preferred modes are being compared to the indicators of the energy justice framework in order if they meet the criteria for a fair procedure and distribution of outcomes. Based on semi-structured interviews the analysis of the data demonstrated that different modes of participation in different phases of the process are being preferred and that a balance between modes of distribution of benefits is preferred. The results indicate that the most preferred modes of participation cannot necessarily address all indicators of procedural justice and that depending on the mode of distribution of benefits and the balance between those modes indicators of distributive justice can be addressed.
\end{abstract}

Keywords: energy transition; energy justice; acceptance of wind energy; modes of participation; modes of distribution of benefits; cooperative development

\section{Introduction}

By virtue of European agreements, The Netherlands has to produce $14 \%$ renewable energy by 2020 [1,2]. In order to reach this goal, the Province of Limburg has committed itself to produce 95.5 MW of wind energy by 2020 [3-7]. The feasibility of this goal seems realistic, since one wind park has been realized and six have been permitted [4]. However, in Limburg wind energy is a renewable energy source that shows differences in the level of local acceptance: some wind energy projects show a relatively high level of acceptance whether others cause a lot of debate [8]. Local opposition to renewable energy projects is often characterised by Not In My Back Yard (NIMBY)-ism, which implies an abstract acceptance of renewable energy by the public, but 'not in my backyard' attitudes on the local and thus the concrete level [9]. It is too simplistic to assume that local opposition of citizens and non-governmental organisations (NGOs) to renewable energy projects is only a selfish consideration. Complex institutional practices are in particular relevant for explaining NIMBY-ism [10]. Factors particularly relevant for causing opposition on the local level are perceived procedural and distributional equity $[10,11]$, in other words, how fair the energy transition is perceived. One way to look into social sustainability of wind energy transitions and address long-term developments that are morally acceptable and talk about values and equity is through the framework of energy justice. The energy justice literature claims that both procedural and distributive justice have to be taken into account in order to call an energy transition just [12]. 
Procedural justice entails the elements in the process of decision-making regarding the establishment of renewable energy projects. A fair decision-making, put into practice by participatory methods, has been described as being the basis of legitimate rules and outcomes [12,13].

Distributive justice entails the outcomes of the decision-making, so the perceived balance between the costs and benefits of the renewable energy project. Important aspects are that the outcomes are equally distributed, that the allocation is just, and the mode of distribution of benefits is taken into consideration [12].

At the moment Limburg has one established wind park in the municipality of Leudal, in the village of Neer. Six other wind parks (Weert, Ospeldijk, Heibloem, Egchelse Heide, De Kookepan, Venlo) have been permitted by the appropriate body, of which two are irrevocable (Ospeldijk and Heibloem). Notwithstanding the fact that in in Limburg importance of participation and profit for the local citizens has been expressed in policy documents and many wind projects in Limburg used modes of participation and distribution of benefits, projects have shown differences in local acceptance. Elements as benefits in the distribution and participation in decision-making seem relevant in the level of acceptance in Limburg and were mentioned as reasons for opposition [14]. There seems to be a difference between the private market operator approach and the (partly) cooperative approach $[4,15]$. Cooperative development means that instead of big private energy companies developing wind parks, local initiators, sometimes framed as citizens, in the form of a corporation develop wind parks [16]. Also in local policy documents preference was given to a substantial percentage of cooperative development of a wind park to increase the level of local acceptance [5]. The preference for local initiated renewable energy constructions has also been concluded in scientific literature, since their method is more bottom up than the top down approach of big energy companies [16]. The private and cooperative approach differ in methods of development regarding the timing of participation, the modes of participation and the distribution of benefits [17-19].

A lot of research has been done on how participation and a fair distributional of benefits increases public acceptance. In the literature different forms and practices of what in general is identified as participation can be found, such as informing, consultation and partnerships $[13,20]$. Likewise, multiple forms of sharing in benefits can be noticed in the literature, such as ownership, community benefits and compensation measures [11,21]. However, understanding of what factors are important for a perception of procedural and distributive justice and what modes of participation and distribution of benefits are most likely to address these factors is understudied. This research aims to provide insight in which modes of participation and distribution of benefits (and in what phase) are perceived as most just and whether these preferred modes can tackle the indicators of energy justice. This paper is structured as follows: Section 2 gives the theoretical framework, Section 3 discusses the methods being used for this research, Section 4 provides the results and Section 5 gives the conclusion and discussion.

\section{Literature Review}

\subsection{Energy Justice}

Justice considerations regarding energy systems are being discussed in the energy justice literature. It is claimed that principles of justice are seen as a requirement in order to call renewable energy transitions sustainable and that not considering justice might erode political support for energy transition efforts [22]. The relevance for justice considerations in energy transitions becomes apparent when looking at the moral implications of our fossil based and renewable based energy systems and looking at the benefits justice considerations can bring to the social acceptance of renewable energy systems. Energy systems are understood as 'multiple interconnected processes of generation and consumption' [23]. Both our fossil and renewable energy systems are to a greater or lesser extend contributing to injustices in society.

The effects of our fossil-based energy system, such as $\mathrm{CO}_{2}$ emissions, cause injustices both at the global level and the local level and therefore have to be tackled from a moral point of view. Even 
though the consequences of our fossil energy system are created by many actors all over the world, the outcomes are often disproportionally felt by the less fortunate in this world. This applies as well for the people living in the global North and the global South [24]. An example of consequences of climate change disproportionally felt by the poor was visible during and after Hurricane Katrina in the Unites States. The less fortunate were less able to protect themselves against the consequences and had more difficulties to recover from the damage, as well regarding health care and reconstruction of their houses [24]. Climate change can therefore result in further inequalities between people and thus increase injustices in society.

The injustices occurring due to the fossil energy system might not be the same as the ones occurring due to new renewable energy systems, but by moving to new renewable energy systems injustices may not be addressed by simply tackling $\mathrm{CO}_{2}$-related injustices. With the transition to renewable energy such as wind, new moral considerations can be observed. For example, the location of the wind turbine, where the profit goes, how the costs and benefits are balanced among members of society and the possible consequences for the affordability of the energy bill [12]. A conflict is noticeable between the overall societal benefits of wind energy, such as cleaner air and profit of the companies involved, and the costs of wind energy, which are concentrated on the local level [11,25].

By looking carefully at the moral implications of energy systems, injustices present due to both the old and new energy system can be phased out [23]. Even though the literature provides different conceptualisations of the concept of energy justice [22,26], they all coincide on that the key aspects of energy justice are distributive and procedural justice. Both modes of justice ought to be present in order to call an energy system or transition towards a new energy system just [12]. The framework of energy justice developed by Mundaca Busch and Schwer makes it possible to assess both old and new energy systems by their identification of indicators for energy justice [23]. These indicators can be traced back to both procedural and distributive aspects.

\subsection{Procedural Justice}

Procedural justice entails the elements in the process of decision-making regarding the establishment of renewable energy projects. Justice is not only the greatest possible outcome of distribution, but also entails the way in which it is distributed [27]. The rationale of that a due process is a prerequisite for just outcomes is that the processes of institutions shape the outcomes of these institutions. This relates to the bias in outcomes of decisions when processes ignore or do not include the ones affected and thus stays in hands of relative powerful groups [28]. Procedural justice is according to the literature being realized by relevant stakeholder participation [12]. In general participation entails citizens involvement in decision-making processes [13]. The degree of participation in wind energy projects is a determining factor for the level of perceived fairness in a decision making procedure and affects the outcomes of that process [13].

Important aspects of meaningful stakeholder participation are (1) who is included and (2) the degree of involvement. Additionally, the meaningfulness of the degree of participation is dependent on the timing and the frequency of the involvement of stakeholders [13]. Participation cannot be identified as one general concept but is divided in different modes based on the degree of influence stakeholders have. The most influential starting point of different definitions of public participation and citizen empowerment is 'The Ladder of Citizen Participation' constructed by Arnstein. According to Arnstein there are different forms of citizen involvement, which vary in their ability to create inclusion and meaningful influence in decision-making processes. In total she identifies eight forms of citizen participation namely: (1) Manipulation; (2) Therapy; (3) Informing; (4) Consultation; (5) Placation; (6) Partnership; (7) Delegated Power and (8) Citizen Control. She argues that only the upper three levels $(6,7$, and 8$)$ create citizen power and a real influence in decision-making [20]. Table 1 shows the forms of participation and its definitions identified by Arnstein. These forms form the basis of identifying and categorising used and preferred modes of participation in wind park developments in Limburg. 
Table 1. Forms of participation identified by Arnstein [20].

\begin{tabular}{|c|c|}
\hline Form of Participation & Definition \\
\hline Manipulation & $\begin{array}{l}\text { Manipulation is about educating the people about the policy idea and/ or } \\
\text { problem. The people being educated have usually no legitimate function or } \\
\text { power. The policy plan is being sold. }\end{array}$ \\
\hline Therapy & $\begin{array}{l}\text { This form of participation puts emphasis on curing the people participating from } \\
\text { their ideas. The goal is to adjust the disagreement showed by the citizens }\end{array}$ \\
\hline Informing & $\begin{array}{l}\text { This form is about informing people of 'their rights, responsibilities and options' } \\
\text { [20]. The citizens can ask questions, but there is no receptiveness for the opinion } \\
\text { of the citizens. It is a one-way flow of, often technical, information from the } \\
\text { decision maker to the citizen. }\end{array}$ \\
\hline Consultation & $\begin{array}{l}\text { In this form the opinion of citizens is asked, but not necessarily taken into } \\
\text { account. Policy options are not available, just consultation on one policy option } \\
\text { takes place. The scope of options is already limited by the people in power. There } \\
\text { are no mechanisms to assure that their opinions will be taken into account. }\end{array}$ \\
\hline Placation & $\begin{array}{l}\text { There is an information flow and the scope of policy options is not limited } \\
\text { beforehand. The expectation is that there is some influence of the less powerful. } \\
\text { However, the powerholders still decide and can outvote the powerless since they } \\
\text { judge the legitimacy of the input. }\end{array}$ \\
\hline Partnership & $\begin{array}{l}\text { In this form 'the power is redistributed through negotiation between citizens and } \\
\text { powerholders' [20]. There is agreement on structures to 'share planning and } \\
\text { decision-making responsibilities' [20]. In this form people can initiate plans, } \\
\text { engage in joint planning and review plans. }\end{array}$ \\
\hline Delegated Power & $\begin{array}{l}\text { Citizens have dominant power in the decision-making and are accountable for } \\
\text { the project. They (citizens) have the power to put things on the agenda, such as } \\
\text { new plans, and the powerholder has to negotiate. }\end{array}$ \\
\hline Citizen Control & $\begin{array}{l}\text { Citizens have control over the budget, are responsible for the process and the } \\
\text { solution. They are in charge of the policy-making and managerial aspects. If final } \\
\text { approval is needed from the city council, it cannot be framed as citizen control. }\end{array}$ \\
\hline
\end{tabular}

\subsection{Distributive Justice}

Distributive justice entails the outcomes of the decision-making, so the perceived balance between the costs and benefits of a renewable energy project. The idea of distributive justice finds its most influential starting point in the social justice literature. In Rawls theory of justice, justice is identified as the fair distribution of primary goods. These primary goods are 'rights and liberties, powers and opportunities, and income and wealth and should be distributed in a manner a hypothetical person would choose if, at that time, they were ignorant of their own status in society' [29]. Distributive justice in energy justice recognizes that both costs and benefits, thus the outcomes of energy systems, are equally distributed among members of society, regardless their position in society [26]. It is basically a question of allocation of technologies and allocation of outputs of these technologies [23]. Wind energy in particular is known for its national or international contribution to cleaner air and reduction of greenhouse gas emissions, but the negative effects are present at a local scale [11]. This net benefit of wind energy is usually not visible on the local level and affects how citizens perceive fairness of the allocation of costs and benefits between 'society, community, local residents and the companies involved' [30]. This leads to perceived unjust distribution of the benefits and costs and thus non-acceptance on the local level [10]. Scientific literature acknowledges three most well-known forms of distribution of benefits, that have the aim to improve the perceived distributive justice and the local acceptance of wind energy: Compensation, Community Benefits and Ownership [11]. Definitions of these modes can be found in Table 2. These forms form the basis of identifying and categorising used and preferred modes of distribution of benefits of wind energy in Limburg. 
Table 2. Forms of distribution of benefits identified by the literature [11].

\begin{tabular}{|c|c|}
\hline Mode of Distribution & Definition \\
\hline Compensation measures & $\begin{array}{l}\text { Compensation measures cover the negative consequences for affected individuals } \\
\text { of wind energy projects, for example regarding the value of property or houses of } \\
\text { affected citizens [11]. Examples exists of developers directly paying compensation } \\
\text { for the perceived costs, but also agreements where it is guaranteed that citizens } \\
\text { can sell their property at the current market value [11]. However, this form has } \\
\text { not been identified as the most effective form of distribution so far, since the line } \\
\text { between bribery and compensation is thin and thus faces the risk of creating trust } \\
\text { issues which results in doubts regarding the fairness of this mode [11,25]. }\end{array}$ \\
\hline Community Benefits & $\begin{array}{l}\text { Community benefits are in contrast to compensation measures not specified to } \\
\text { just a couple of individuals, but create benefits for the whole community and thus } \\
\text { compensate in that sense for the local consequences of wind energy projects [11]. } \\
\text { Community benefits are based on the equality principle since the aim is to give the } \\
\text { people involved an equal share of the benefits [30]. An example is a local reduced } \\
\text { electricity tariff for the affected people or the community [10]. Also, annual } \\
\text { compensation payments to the community or part of the profit going to local } \\
\text { funds can be noticed in the literature as a form of community benefits [10,11]. }\end{array}$ \\
\hline Ownership & $\begin{array}{l}\text { Ownership measures can be seen as the most direct form of financial participation } \\
\text { in wind energy projects. There are different forms of citizens' financial } \\
\text { participation in which the degree of ownership differs. It ranges from citizens } \\
\text { investment by shares to full community ownership of a wind turbine [11]. } \\
\text { Ownership measures in the form of shares are based on the equity principle, since } \\
\text { the financial benefits are proportional to how big someone's share or investment } \\
\text { is [30]. }\end{array}$ \\
\hline
\end{tabular}

With the necessity to transform the energy system in a reasonable time, emphasis has been put on the need for public support and local acceptance. International, national and regional policy documents address the social challenges of wind energy. Participation and equal distribution of benefits are expressed as important components to create public and local support.

\section{Methods}

In order to get insight in the current ways of operating wind parks in Limburg and draw conclusions about the most preferred modes of participation and distribution of benefits the following conceptual framework was being used to test the data.

Within the procedural justice aspect current used mode(s) of participation, in both the cooperative approach and private market approach, were analysed. In order to be able to draw conclusions on most preferred modes of participation (and in what phase), the current used modes were compared with the factors being mentioned in the data as relevant for a perception of a just procedure, in order to conclude which mode(s) are perceived as most just and if this corresponds with the modes used in both the private and cooperative approach. The modes that are perceived as most just were tested on their ability to tackle procedural justice indicators presented in Figure 1. These indicators are bias, ability to be heard, institutional representation, access to consultation, information disclosure, objectivity \& adequacy \& timeliness, and mobilisation of local knowledge.

Regarding the distributive justice aspect current used mode(s) of distribution of benefits, in both the cooperative approach and private market approach, were analysed. In order to be able to draw conclusions on the modes preferred modes of distribution of benefits, the current used modes were compared with the factors being mentioned in the data as relevant for the perception of a just distribution of benefits, in order to conclude which mode(s) are perceived as most just and if this this matches the modes used in both the private and cooperative approach. The mode(s) that are perceived as most just were tested on their ability to tackle distributive justice indicators presented in Figure 1. These indicators are distribution of costs and distribution of benefits. 


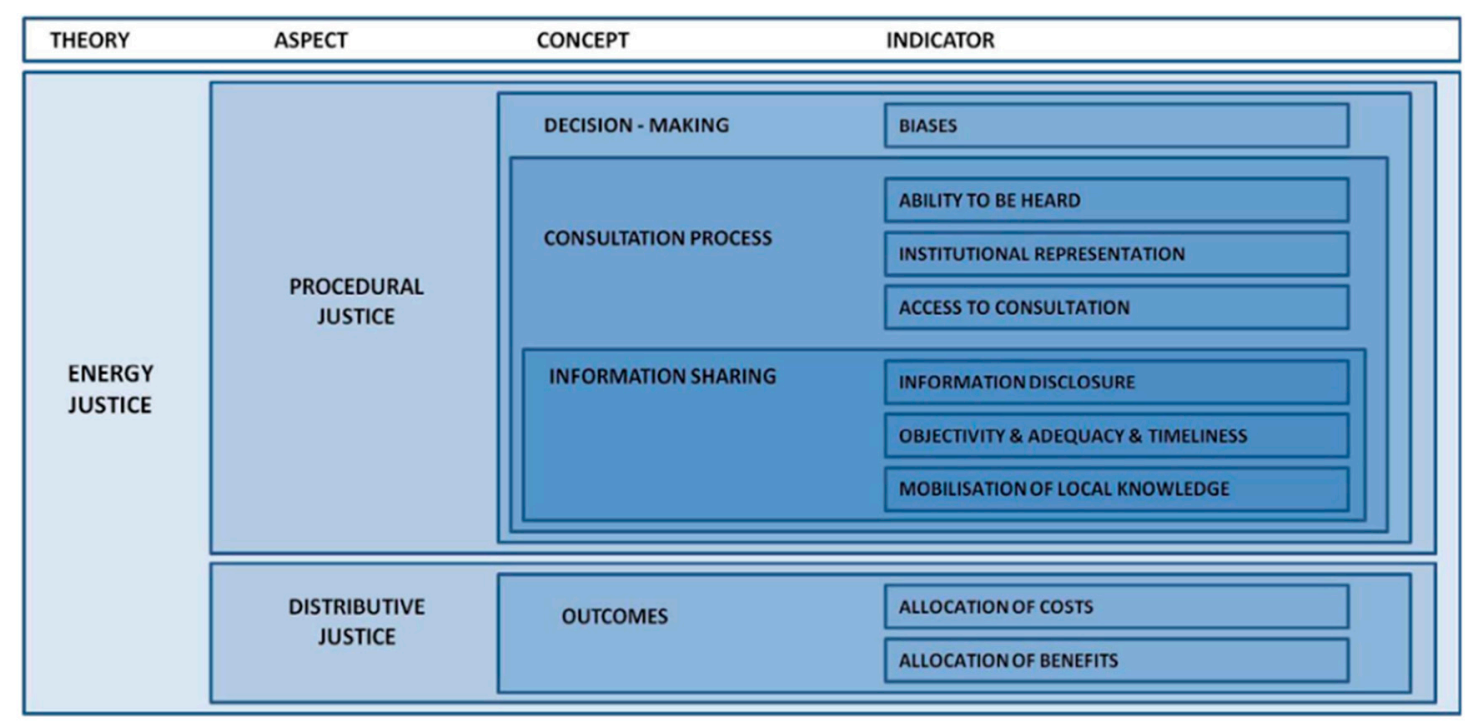

Figure 1. Overview of the conceptual and analytical framework of energy justice [12].

This study makes use of a case study approach and qualitative data collection. With the literature on the basis, a case study analysis of the already permitted wind parks in Limburg was done in order to research the procedures and the outcomes of the wind parks. Only permitted wind parks by august 2019 were included because of the necessity to have a clear boundary to compare completed processes of decision-making and distribution of benefits. Table 3 presents the seven permitted wind parks by ugust 2019. A case study approach is an appropriate tool to identify actor groups and get an elaborate understanding of which forms of participation and distribution of outcomes are used most frequently and which forms are most preferred by different stakeholder groups. In total seven wind parks in Limburg have been permitted. At present, all of them are supposed to have cooperative development elements. However, in Venlo and Neer, the starting point was a private development approach, but during the development process it started to include a cooperative development approach.

Table 3. Permitted wind parks in Limburg by August 2019.

\begin{tabular}{cccc}
\hline Number & Wind Park & Established & Balance Private/Cooperation \\
\hline 1. & Wind park Venlo & No & Privately initiated, but promised to include cooperations. \\
2. & Wind park Neer & Yes & Privately initiated, but one turbine 100\% of cooperation. \\
3. & Wind park Weert & No & Share between private company and cooperation. \\
4. & Wind park Ospeldijk & No & Share between private company and cooperation. \\
5. & Wind park Heibloem & No & $100 \%$ cooperation. \\
6. & Wind park Egchelse Heide & No & Share between private company and cooperation. \\
7. & Wind park De Kookepan & No & $100 \%$ cooperation. \\
\hline
\end{tabular}

Qualitative data in the form of semi-structured interviews was used for this research. Perceived justice, indicators for justice, and forms of participation and distribution of benefits are concepts that have subjective elements and are therefore harder to quantify. The conceptual framework of this research is more appropriate to be analysed and tested with qualitative methods to fathom different values and perceptions. Besides that, qualitative research can be useful in adding on the theories discussed in the literature review. To make sure to get valuable information out of the interview open-ended questions were the basis of getting in depth understanding of the stakeholders' perceptions, opinions, values and knowledge [31]. During the semi-structured interviews by phone, different types of open-ended questions were being asked, known in the literature as knowledge questions, feeling questions and background or demographic questions [31]. These questions (see Appendix A) aimed for getting information about the developments of the wind parks, insights in the perceived justice elements, and information of the stakeholders and their interests. The latter sort of questions were 
used to check whether the stakeholder list should be elaborated upon and to check the categorisation of the stakeholders based on their own input.

With the imperative approach the first stakeholders of the permitted wind parks in Limburg were identified. Actors were identified through literature and case study analysis. In order to prevent bias by the author in the first attempt of identifying stakeholders and create a fair representation of stakeholders, the imperative approach was complemented with help of the snowballing sampling technique. Snowball sampling entails that persons within the initial stakeholder categories will be interviewed and further stakeholders will be identified with help of these interviews [32]. After identifying the stakeholders and performing a double check by the author with analysis of open- ended 'background' questions they were categorised based on their role in a governance system. Based on the techniques described, stakeholders were categorised as (1) Local wind energy cooperations (2) Non-governmental organisations and (3) Citizens, which is elaborately presented in Table 4.

Table 4. Categorisation of stakeholders.

\begin{tabular}{|c|c|c|}
\hline Stakeholder Categories & Stakeholders & Case Studies \\
\hline \multirow{4}{*}{ Local wind energy cooperations } & $\begin{array}{l}\text { Energy cooperation A: Energy cooperation } \\
\text { Newecoop }\end{array}$ & Ospeldijk \\
\hline & $\begin{array}{l}\text { Energy cooperation B: Energy cooperation } \\
\text { Zuidenwind }\end{array}$ & Neer (only the Coöperwieck) \\
\hline & $\begin{array}{l}\text { Energy cooperation C: Energy cooperation } \\
\text { Leudal Energie/Energy cooperation Weert } \\
\text { Energie }\end{array}$ & De Kookepan \& Weert \\
\hline & $\begin{array}{l}\text { Energy cooperation D: Energy cooperation } \\
\text { Reindonk Energie }\end{array}$ & Venlo \\
\hline \multirow{5}{*}{ Citizens } & Citizen A: Village consultation Egchel & $\begin{array}{l}\text { Egchelse Heide + Neer (including De } \\
\text { Coöperwieck) }\end{array}$ \\
\hline & $\begin{array}{l}\text { Citizin B: Direct stakeholder and representative } \\
\text { of village council Ospeldijk }\end{array}$ & Ospeldijk \\
\hline & Citizen C: Village cooperation Boerderijweg & $\begin{array}{l}\text { Neer (including De Coöperwieck) + } \\
\text { Heibloem }\end{array}$ \\
\hline & $\begin{array}{l}\text { Citizen D: NLVOW (Dutch Association for } \\
\text { People living near Wind Turbines) }\end{array}$ & Venlo + included in general way \\
\hline & Citizen E: Village consultation Boekend & Venlo \\
\hline \multirow{3}{*}{ Non-governmental organisations } & $\begin{array}{l}\text { NGO A: NMFL (Nature and Environment } \\
\text { Federation Limburg) }\end{array}$ & Venlo + included in general way \\
\hline & $\begin{array}{l}\text { NGO B: NMFL (Nature and Environment } \\
\text { Federation Limburg) }\end{array}$ & Weert + included in general way \\
\hline & $\begin{array}{l}\text { NGO C: LLTB (Limburg Agriculture and } \\
\text { Greenery Federation }\end{array}$ & Heibloem + included in general way \\
\hline
\end{tabular}

In total 32 stakeholders were emailed, of which 12 positively responded. The point of saturation was determined on how much new information was yield after adding new stakeholders. Furthermore, with the aim to have a fair representation of stakeholders, the point of saturation also included taking into account that every category of stakeholders consisted of about the same amount of interviewees. To guarantee a fair balance and the unlikeliness of obtaining new information by adding one more identical or too powerful stakeholder the point of saturation was reached by $37.5 \%$ response.

For the analysis of the data collected the coding method was used. With help of the software program Atlas.ti reoccurring concepts and themes could be looked for in order to analyse the ideas expressed by the interviewed stakeholders. By constant comparison it was checked if the identified concepts fitted into identified themes. The collected themes were structurally compared with the aim to define categories. The interviews gave elaborate insights in among others perceived justice and preferred justice. With the insights gained from the coded interviews the conceptual framework, presented in Figure 2, was tested. Examples of the categories are: mode of participation, mode of distribution, and factors for a perception of justice. Codes were among others phase of involvement, 
policy options, individual benefits, and influence. The full list of the codes identified can be consulted in Appendix B.

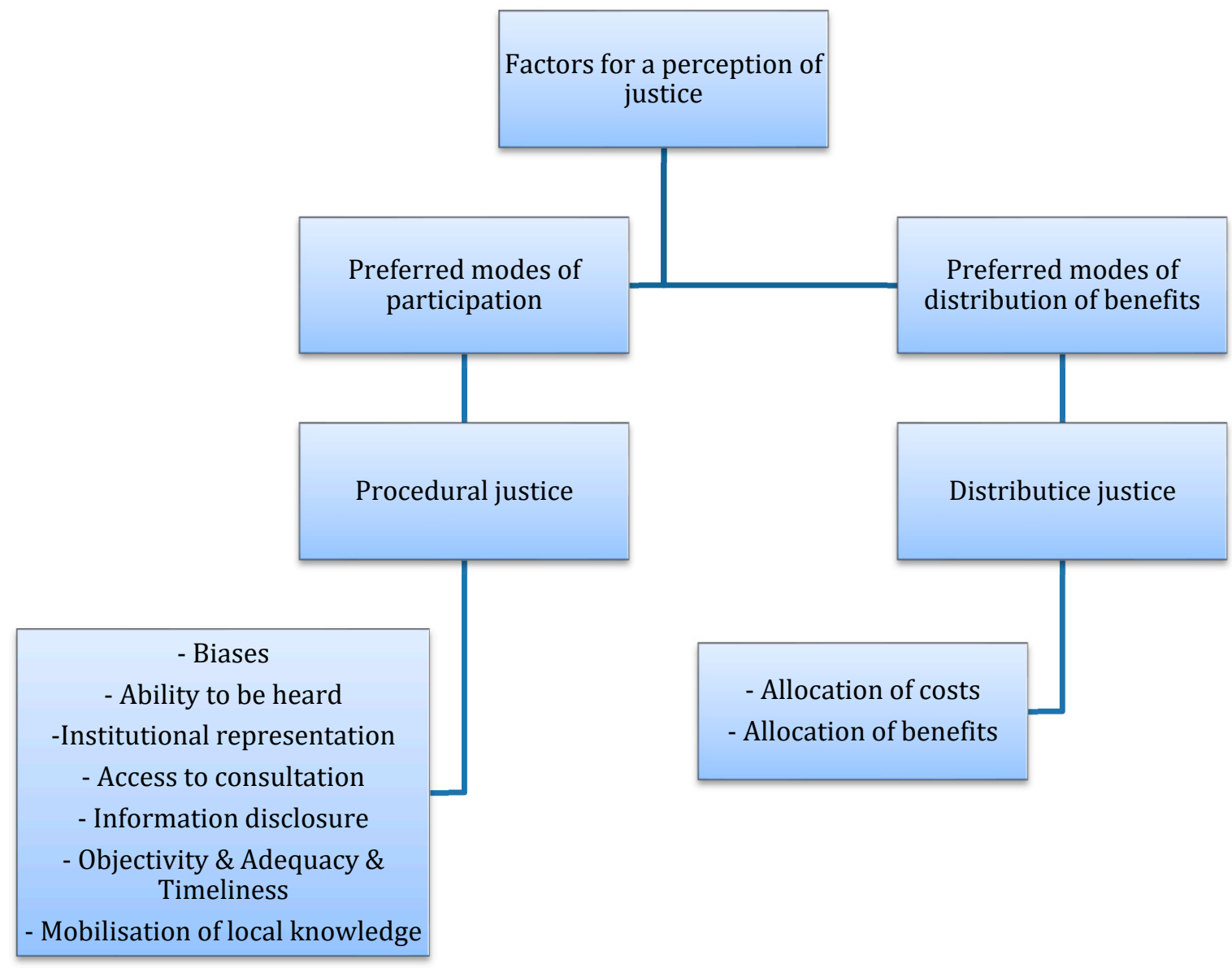

Figure 2. Conceptual framework of this research.

\section{Results}

Insights from the coded interviews resulted in the collection of the following elements: the currently used modes of participation and distribution of benefits and factors for a perception of fairness in both the procedure and the distribution of benefits. This section addresses the results regarding participation and distribution of benefits.

\subsection{Participation}

\subsubsection{Used Modes of Participation in Limburg}

Based on the interviews three main phases of wind energy project could be identified, namely the development of ideas phase, of which the location choice is a sub-category, the consultation process at the municipality, which can be identified as the implementation phase, and the distribution of benefits, which can be identified as the exploitation phase. It differs per development approach (private or cooperative) what modes of participation are used in what phase. On top of that, it could be notified that used modes of participation differ per stakeholder category. This section describes the three phases of a wind park development in which in every phase a distinction is made between a private and cooperative development approach and stakeholder categories.

Phase 1 (Development of Ideas phase)

Private development 
Within a private approach the development of ideas phase, including the location choice, citizens predominantly experience the mode information as mode of participation. Stakeholders express the technical details about wind energy being mentioned, such as cast shadow and noise, but miss the context of the renewable energy goals of the municipality and the argumentation about the location choice. Data shows that citizens are in general not included via consultation or 'higher' modes of participation in this phase.

For NGOs a balance between cooperation and placation as mode of participation is noticeable in this phase. In most cases they are involved in the policy making phase of setting criteria for wind energy projects. In some wind energy projects the policy options, such as the location of the wind park or development criteria, are not already narrowed down by the people in power. Even though this shows elements of placation, their influence differs per case. In general they are considered as important partners also in the development of ideas phase, but the degree of their interest being taken into account differs per wind energy project.

(Partly) Cooperative development

In general, citizens are being informed in this phase, mostly materialised in the form of an information evening. Again, in the majority of the cases in Limburg, the location or the estimated project area of the wind park has at this time already been determined without citizen influence. So the decision on the location seems to be without modes of citizen involvement higher than information. Despite the cooperative development using the same mode of participation as the private approach regarding the location choice, the cooperative approach seems to involve citizens differently throughout other aspects in this phase of development. The information disclosure, transparency of the initiators, the frequency of involvement and the inclusion of citizens' interests are significantly more elaborate. Except from the location choice, citizen involvement can be characterised as consultation and sometimes even shows elements of placation, since policy options regarding the location are already narrowed down, but citizens' opinions are being asked for. The degree to which citizens' visions are being heard and create an expectation of having influence defines whether elements of placation are being present and differs per wind park development. Full placation could not be identified since the scope of options is already limited.

In the cooperative approach one element in this phase is being characterised by the partnership mode of participation, namely the division of ground compensation, which is a form of distribution of benefits. Usually the distribution of benefits takes place in the exploitation phase, but data confirms that in a lot of cooperative cases elements of distribution of benefits are already present in the first phase of the development of a wind park and make use of participatory methods. Even though citizens have no influence on the location of a wind turbine, directly affected landowners of the searching area have influence, in the form of co-decision, on the budget of the ground compensation, before the decision of the exact location of a wind turbine is been taken. Not only the landowners of the field where the wind turbine is going to be established are getting compensated, but all the landowners of the searching area, so before the location has exactly been decided upon, decide together how they are going to divide the money of the ground compensation budget. By giving a limited number of citizens, namely landowners in the searching area, considerable power to co-decide on the division of ground compensation, this element in the first phase of the development of a wind park can be characterised as partnership.

While in a private development approach, greater variations regarding modes of involvement between citizens and NGOs are visible, this difference seems to diminish in a cooperative development. The involvement of NGOs balances between consultation and placation, since in general their opinion is being asked for, even regarding the location choice, but the expectation that their interest being taken into account is context specific. This shows that for NGOs the modes of participation being used, in both the private and cooperative development approach are comparable.

Phase 2 (Implementation phase) 
Private development

In general, the moment of any more influential form of participation for citizens is the moment when the location of the wind turbine is already determined but needs the approval of the city council. That is the moment for citizens to express their opinion via a public participation procedure. This mode of participation can be qualified as consultation, since the scope of options is already limited, since the location of the wind turbine has already been narrowed down to one option. Despite the fact that in this procedure citizens' opinions are being sought as there is no mechanism to ensure that citizen opinions will be taken into account or have particular power to influence the decision making process.

Interestingly NGOs seem not to be unambiguous regarding the expectation that their opinion is being considered and taken into account. Consultation and elements of placations are visible, in which the degree of elements of placation being present differs per wind energy project.

(Partly) Cooperative development

The same public participation procedure at municipal level is visible in a cooperative development approach. Even though citizens' opinions are better heard in the development-of-ideas-phase the consultation process in the implementation phase on the municipal level is being criticized. They express the absence of any mechanism to ensure that citizens' opinions are being taken into account. Besides that, the overarching interest of the municipality to reach the renewable energy goals is seen as a limitation to balance the interests correctly and influences the expectation of citizens that their opinion is being considered and taken into account. Again, for NGOs no significant difference could be noticed between a cooperative and a private development approach in this phase.

Phase 3 (Exploitation phase)

Private development

Concerning the exploitation phase, so after the permit has been given, the data seems to suggest that no public is involved anymore in any further phase of the process of a privately developed wind energy project. Neither citizens nor NGOs seem to have a role in the exploitation phase where usually the division of profit is being materialized.

(Partly) Cooperative development

Data confirms that in a cooperative developed wind park there is a role for citizens in the exploitation phase. This phase shows elements of partnership since there is an agreement to share the decision-making responsibilities to a certain extent, namely the division of money within the mode of distribution of benefits. For example, in the case of community benefits, co-decision is present on how the money within that mode is going to be spend. Citizens do not necessarily have influence on what modes of distribution there are going to be, or the budget of the mode, but they have influence on the division of the budget within these modes of distribution.

For NGOs it could not significantly be concluded that they have a role in this phase in a cooperatively developed wind park. Interestingly this is the only phase where NGOs seem to be subject to a lower mode of involvement than citizens. However, there is one example present where they are involved in the exploitation phase in the form of a working group deciding on how to divide the budget for nature repair measures.

Table 5 shows an oversight of the used modes of participation in wind development in Limburg. 
Table 5. Current modes of participation in wind development in Limburg ${ }^{1}$.

\begin{tabular}{lll}
\hline $\begin{array}{l}\text { Phases of Wind Park } \\
\text { Development }\end{array}$ & Private Development Approach & Cooperative Development Approach \\
\hline Phase 1 (development of ideas) & Information & $\begin{array}{l}\text { Information + Consultation + Elements of } \\
\text { placation + (Elements of partnership *) }\end{array}$ \\
& $\begin{array}{l}\text { Information + Balance between } \\
\text { consultation and placation }\end{array}$ & $\begin{array}{l}\text { Information + Balance between } \\
\text { consultation and placation }\end{array}$ \\
\hline Phase 2 (implementation) & Consultation & $\begin{array}{l}\text { Consultation } \\
\text { Consultation }\end{array}$ \\
\hline Phase 3 (exploitation) & Consultation & Elements of partnership \\
\hline
\end{tabular}

Note: Grey: used modes of participation for citizens; Blue: used modes of participation for NGOs; *: only concerns a small group of people, namely landowners of the search area.

\subsubsection{Factors Important for a Perception of Procedural Justice}

Regardless their position in the governance system and the development approach of the wind park, stakeholders gave similar answers to the question of what factors are important for a perception of fairness in the process. First of all, stakeholders mentioned the factors timing of the involvement and feeling taken seriously. Those two factors are interconnected. An important note is that almost all stakeholders mentioned wanting to be involved in the process of a wind park development as soon as possible and that this consultation is easily accessible for every stakeholder. With the ability to think along regarding alternative wind park locations in an early phase and the guarantee that their opinion is being asked and taken into account the factors 'as soon as possible' and 'feeling taken seriously' would be met. Feeling taken seriously is linked to that the interest and claims of the stakeholders are taken into account. This does not necessarily mean that they want to have a (co-) decision-making role, but they want at least a facilitated influence on the process by seeing their interests being represented. Being taking seriously starts with collectively informing the people and good communication. Without transparency people cannot become informed by the overall project according to the data. Also inclusivity and collectivism, which entails being involved all at the same time and with different stakeholders together, is mentioned as a factor of importance to create a fair process. On top of that, the adequacy of information could be identified as a factor being important for a correct information flow and a perception of fairness in the process.

Based on the factors being mentioned as important for a perception of procedural justice and supplemented with one factor being mentioned as important for a perception of distributive justice, concerning co-decision in the division of benefits, the stakeholder express their preference for the mode of information in the development-of-ideas-phase, but supplemented with placation in the division of the location, and partnership in the division of benefits in the development of ideas- and exploitation phase. However, a preference for the latter mode of participation could not be concluded among non-governmental organisations.

Table 6 shows an oversight of the preferred modes of participation per phase in wind park development in Limburg.

\subsection{Distribution of Benefits}

\subsubsection{Used Modes of Distribution of Benefits in Limburg}

Private development

Data shows that in the private market approach ground compensation for the landowner where the turbine is going to be located and individual compensation for residents is the most common form of distribution of benefits. Due to the small percentage of this individual compensation compared to the total profit data shows that in most cases the biggest percentage of the revenues goes to the market operator. No restrictions exist where this company has to be located, which means profit can also end 
up in other countries. Next to individual compensation, it is not impossible that a private market operator makes use of a community fund, which entails benefits measurements for the region. In some wind energy projects even private market operators give the option to participate financially in a wind park, but other requirements apply such as a minimum amount of money investment. In general, the perception exists that regardless the mode of distribution of benefits being used the distribution of benefits is not equally balanced in a privately developed wind park, taking into account the small percentage of the revenues ending up locally.

Table 6. Preferred modes of participation per phase in wind park development in Limburg.

\begin{tabular}{ll}
\hline Phases of Wind Park Development & Preferred Modes of Participation \\
\hline & $\begin{array}{l}\text { Information + Placation + (Partnership*) } \\
\text { Stakeholders want to be collectively informed and included when the location of the } \\
\text { wind park has not yet been determined, so that there is still an open discussion about } \\
\text { the location. Besides that, they want their interests to be taken into account. They } \\
\text { would like to think along about alternative locations. This does not mean that they } \\
\text { necessarily want to take part in the decision-making process, which they generally still } \\
\text { see as a task for the municipality. In conclusion they want a broader scope of options } \\
\text { and they want their interest being taken into account. }\end{array}$ \\
\hline Phase 2 (Implementation) & $\begin{array}{l}\text { Decision making in hands of the municipality } \\
\text { Partnership } \\
\text { Data shows that the only part where citizens prefer a higher form than 'placation' as a } \\
\text { form of participation is regarding decisions on the distribution of benefits. They do not } \\
\text { necessarily want to take part in deciding on the budget or what modes of distribution } \\
\text { will be available, but they do want to determine what will happen to the money within } \\
\text { a certain mode of distribution. } \\
\text { * In the 'development of idea' phase, citizens indicate that they would also like to make } \\
\text { a collective decision about the distribution of the ground compensation. However, this } \\
\text { concerns a small group of landowners that is included in this division in this phase. } \\
\text { Interestingly, the NGO did not indicate that it would prefer partnership as a form of } \\
\text { participation at any stage. }\end{array}$ \\
\hline
\end{tabular}

Note: * shows that partnership is also preferred in the first phase of wind park development, but only concerns a small group of stakeholders, namely landowners.

Cooperative development

As in a private approach, different modes of distribution of benefits are present in cooperative cases in Limburg. In almost all cases collective ground compensation is present. Whereas in the private approach only the landowner of location of the wind turbine would receive ground compensation the cooperative approach includes the searching area too in the ground compensation budget, which means inclusion of the haze parcels of the estimated location too. Furthermore, all wind parks show collective compensation measures in the form of a community fund. The budget of this fund is most of the time determined by following at least the NWEA norm of 50 cent per MWh. Within this community fund members of the cooperation can bring in ideas for projects they want to realize in the region. Most of the time the projects have to fulfil required elements of liveability or sustainability. It depends per project whom is included to receive the benefits of the community fund. Data shows differences regarding individual compensation measures between cooperations. While in some cases individual compensation measures are present, others explicitly do not make use of such a mode.

Different formats of community benefits are visible in a few cooperations, such as an energy fund and a nature fund, present in Ospeldijk and De Kookepan. These modes of distribution of benefits are not visible in every cooperatively developed park but are elaborate forms of letting the profit end up locally. For example, in Ospeldijk the intention is to facilitate the energy transition of the region with the energy fund budget and is increase in nature quality economically facilitated with the nature fund in De Kookepan.

The last form which is present in a majority of the cooperatively developed cases in Limburg is that as a member of the cooperation you can participate financially, by investing money in the energy cooperation with yield as return favour for the investment. Regardless the mode of distribution, with a cooperative development approach the benefits of the wind energy projects will in general land locally. 
Data shows that even though the intention is to let the profit end up locally, no requirements are set in general on investing money in an energy cooperation. This means there is no guarantee that only local citizens will invest, which might weaken the intention to let the profit end up locally.

Table 7 shows the current modes of distribution of benefits of wind parks in Limburg.

Table 7. Current modes of distribution of benefits of wind parks in Limburg.

\begin{tabular}{cc}
\hline Private Developed Wind Park & Cooperative Developed Wind Park \\
\hline Individual compensation (not transparent) & Individual compensation (transparent) \\
Community fund & Community fund \\
Ownership in the form of financial participation & Ownership in the form of financial participation \\
& Energy fund * \\
& Nature fund * \\
\hline
\end{tabular}

* These modes are only present in two cooperatively developed wind parks in Limburg.

\subsubsection{Factors Important for a Perception of Distributive Justice}

Regardless the development approach of the wind park, stakeholders express that the most important factor for a perception of a fair distribution of benefits is that the profit ends up locally. Also, trust and a fair treatment in the process were mentioned as factors that influence the perception of fairness in the distribution of benefits.

Besides that, a factor specifically mentioned by citizens, is the partnership mode of participation being present in the decision-making concerning the sharing of the benefits. It is not necessarily clear if they want to co-decide on what modes there are going to be or the budget of it, but it can be concluded that they want to co-decide on how the money is going to be distributed within a certain mode. Moreover, they express that there has to be a certain balance between the budget available per mode. This entails for example that money available for ground compensation and individual compensation are in equal proportion. This balance of budgets links with the importance of transparency of the modes and its budgets, which is another factor that creates a fair perception of the distribution of outcomes.

Data shows that there are differences between the focus of the distribution of benefits between a privately developed wind park and cooperatively developed wind park. Privately developed wind parks especially differ in the way they balance the local and non-local profit, and the transparency of the money flow. An example of the lack of transparency is the non-collective approach regarding the ground compensation, where it is not clear to the haze parcels what amount of money the landowner received. With a private approach it is not impossible that some of the profit ends up locally, but the percentage of what ends up locally and what not is not in proportion according to the data. In cooperatively developed parks data shows that the starting point is to let the profits end up locally. Different modes of distribution of benefits are recognizable in order to achieve this. In Limburg it differs per cooperative case which modes of distribution of benefits are present. As well individual compensation, community benefits and investment opportunities are identifiable in the case studies.

Taking into account the factors being mentioned as important for a perception of distributive justice it can be concluded that stakeholders do not prefer one mode of distribution of benefits over the other, they preferably see a combination of modes in which they have influence regarding the division of the budget and that are transparently balanced.

\section{Conclusions and Discussion}

Taking into account the implication of the most preferred modes of participation per phase of development and comparing it with the procedural justice indicators the most preferred modes of participation, where citizens and non-governmental organisations are adequately and correctly informed, and have an advisory role which is being taken into account, can address among other things the indicators 'ability to be heard', 'information disclosure', 'objectivity \& adequacy' and 
'mobilisation of local knowledge'. When the inclusiveness and timing of the invitation to be involved are considered also the indicators 'timeliness', 'institutional representation' and 'access to consultation' can be addressed with these modes. Taking into account the preference for placation over higher modes of participation in the first phase of development of a wind park, the indicator 'biases' in decision-making is harder to address. With powerholders, in this case the municipality, still being able to judge the legitimacy and outvote the input of citizens and Ngo's in the second phase of the development of a wind park, it is not guaranteed that their interests are properly considered. The double role of the municipality to on the one hand fulfil the renewable energy goals and on the other hand weigh the interest of stakeholders makes critiques regarding their incompetence to balance the interest properly plausible. Considering the preference for partnership as mode of participation in the division of benefits does not change this. This higher mode of participation concerns only a small element of the decision- making regarding the distribution of benefits in the and does not take away the risk of biases in the overall decision-making process regarding a wind park.

With no preference for one mode of distribution of benefits over the other, no general answer on their ability to tackle the distributive justice indicators can be given. A combination of modes addressing the factors being mentioned as important for a perception of distributive justice has the preference. Regardless of the mode preference is given to let the profits land locally and the possibility of co-decision within the modes of distribution of benefits. The relevance of a combination of modes might become apparent when looking at the ability of individual modes to address all factors of importance for a perception of distributive justice. With no general conclusion on what mode is most appropriate to address these factors a critical note has to be made by the 'investment' mode of distribution. Even though data confirms that the factor that profit has to land locally is of importance, the 'investment mode' cannot guarantee this completely. With no requirements on whom can invest, also actors not living in the region are able to invest and yield profit. This makes the ability of this mode to address factors important for a perception of distributive justice questionable. Figure 3 shows what indicators of procedural justice could be tackled by the most preferred modes of participation and shows that it could not be confirmed which indicators of distributive justice could be tackled.

This research contributed to the existing scientific literature by getting (1) insight in what modes of participation are most preferred in what phase of a wind park development by making nuances regarding what modes are perceived as most just in regard to specific elements within the process. In view of different aspects of the decision making it showed for example that regarding the location choice another mode of participation is being preferred than regarding the distribution of benefits. Besides that, (2) it showed that a combination of modes of distribution of benefits is being preferred over one specific mode, but that the ability of individual modes to address all factors of importance for a perception of distributive justice is being questioned. Subsequently, this research showed that (3) there is a discrepancy between the most preferred modes of participation and their ability to address the procedural justice indicators.

In view of other research, the following similarities and differences can be identified:

Concerning the modes of participation, the research of Langer, Decker and Menrad confirms, even though the modes have been categorised differently, that information, consultation (in this research identified as placation), cooperation (in this research identified as partnership) have a positive influence on the acceptation of wind turbines on the local level. Moreover, they conclude that transparency, information as well as inclusion of citizens in the decision-making enhance the level of acceptation [13]. The latter could not be concluded out of the data of this research, since a distinction on what they want to co-decide has to be made and turns out to be only regarding the distribution of benefits. Regarding the ability of the preferred modes of participation to tackle procedural justice indicators further research has to find out if higher modes of participation are more likely to address the indicator 'biases' since that question was out of the scope of this research. 


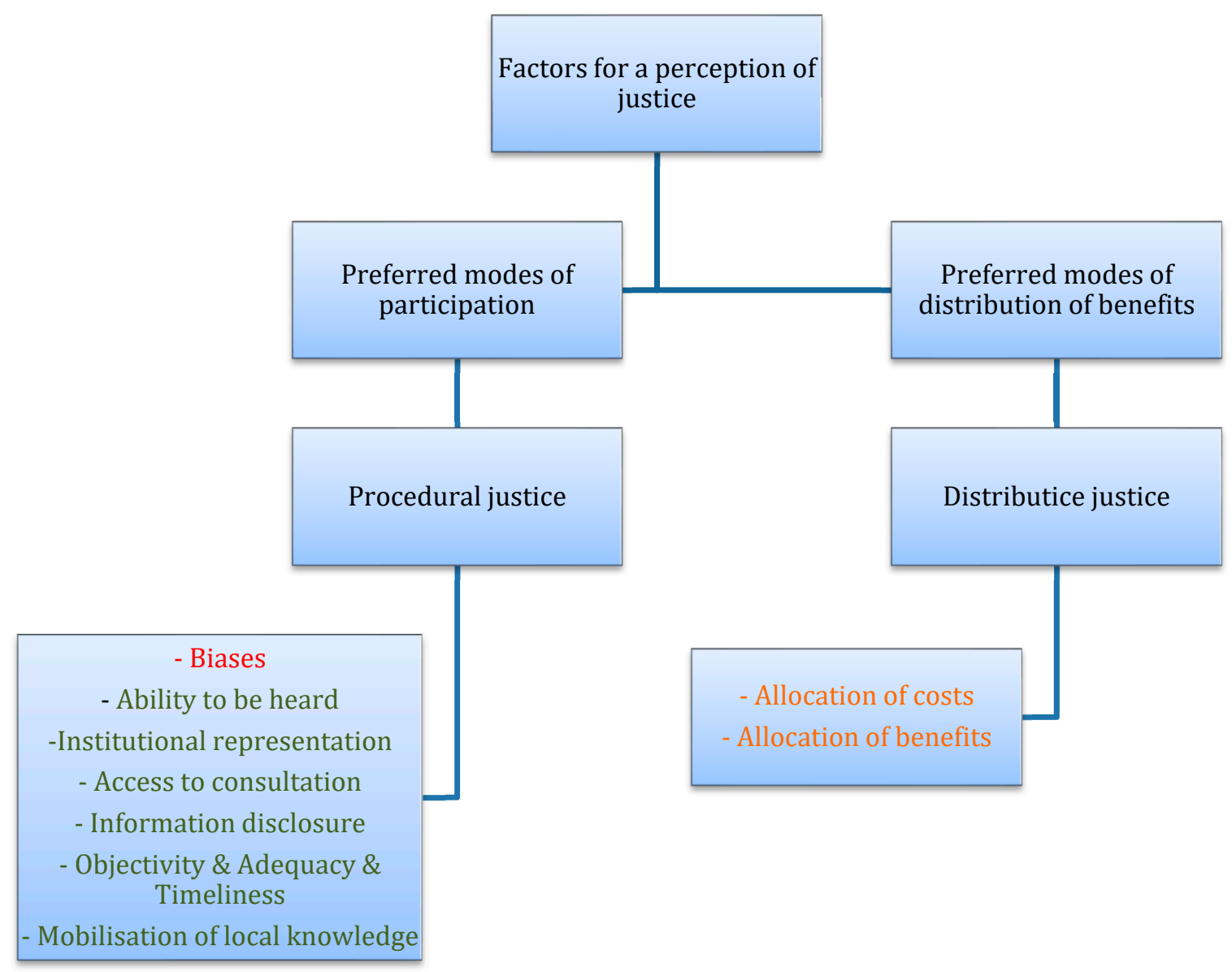

Figure 3. Tested conceptual framework. (red means this indicator is not likely to be tackled; green means this indicator can be tackled; orange means it cannot significantly be confirmed these indicators can be tackled).

Regarding modes of distribution and related factors that enhance acceptation research conducted by Lienhoop confirms that the most important factor to create acceptation is that profit ends up locally. Comparable to the data results in this research, Lienhoop's research confirms that humans do not necessarily always act to maximize their own benefits. Transparency and a combination of modes seems more desirable [10]. Lienhoop confirms that only financial investment as a mode is not desirable, since it can create the risk of not being affordable for everyone. This is comparable to the results in this research, where the possibility of this mode to tackle distributive justice indicators is being questioned. Further research has to find out whether the investment mode of distribution of benefits is an appropriate form to distribute the profits equally. As mentioned already, with the investment mode critical notes have to be taken into account whether the indicator of a just allocation of benefits can be guaranteed. Concerns are that this mode facilitates investments from other regions and is more attractive for higher incomes. This raises questions on whether this form is appropriate to tackle the indicators of distributive justice. Further research has to find out if this mode is also able to address the equality principle. Even though other studies show that the mode of community benefits leads to the highest level of acceptance, this is being questioned in this research, with concluding remarks emphasizing the importance of a variation of modes [25].

For this research a conceptual framework was being used and a comparison between perceived justice and the energy justice framework was being made. Out of the data it could be concluded that regarding the procedural justice indicators it matches with the factors being mentioned as important for procedural justice. However, the indicator 'biases' was mentioned as a barrier in the second phase, 
but data could not confirm stakeholders want a higher form of participation in that phase to tackle this indicator.

The data in this research did only show differences between initially privately developed wind parks and (partly) cooperative wind parks. However, the scope of this research did not allow a comparison between $100 \%$ cooperatively developed wind parks and partly cooperatively developed wind parks. Further research is suggested in order to draw conclusions whether there is a difference in perception of justice between $100 \%$ cooperative wind parks and partly cooperative wind parks.

Further testing of the conceptual framework and the energy justice framework on other renewable energy transitions and systems, for example solar fields, is recommendable in order to test if indicators of the energy justice framework will be matched in other circumstances and if the perception of justice differs per source of renewable energy development.

Author Contributions: Conceptualization, N.K.; methodology, N.K.; validation, V.V. and R.B.; formal analysis, N.K.; investigation, N.K.; resources, N.K.; data curation, N.K.; writing—original draft preparation, N.K.; review and editing, V.V. and R.B.; visualization, N.K.; supervision, V.V. and R.B.; project administration, N.K.

Funding: The research presented in this paper received funding from the European Union's H2020 Research and Innovation program under grant agreement number 727642 ("ENERGISE"). The sole responsibility for the content of this paper lies with the authors.

Acknowledgments: I want to thank the Province of Limburg for facilitating the technical materials available to conduct the research.

Conflicts of Interest: The authors declare no conflict of interest.

\section{Appendix A}

Translation of the interview questions in English:

1. Can you tell me about the development of the plans for this wind farm?

2. Can you tell what is your role concerning the wind park?

3. How were you informed about the plans of the wind project?

4. When were you informed of the plans for this wind project?

a. (Question for clarification; Was the decision about where the project would be realized already taken?)

b. (Question for clarification; And if so, by whom?)

5. What are the advantages of this wind energy project?

a. (Question for clarification: How does the community benefit from the wind project?)

6. What are the disadvantages of this wind energy project?

a. (Question for clarification; In what way does the community experience disadvantages of this wind project?)

7. What is your opinion on the distribution of benefits of the wind energy project? (profit, employment, cost of electricity)

8. What is your opinion about the distribution of the disadvantages of the wind energy project? (maintenance, environmental disadvantages)

9. What do you think is the best/most effective way to share the costs and benefits of a wind energy project?

10. Which factors are important to you in the distribution of the benefits/disadvantages of wind energy projects?

a. (Question for clarification; Which factors are important to have the feeling that the distribution of costs and benefits is sound/fair?) 
11. Who are involved/have been able to participate in the development and decision-making of this wind energy project?

12. Can you tell how you are involved/have been able to participate in the plans for the wind project?

a. (Question for clarification; Or in the decision-making process?)

13. What did you think of the way in which you were involved/have been able to participate in the decision-making process?

14. What did you think of the timing of your involvement in the decision-making process of the wind project?

15. What was your influence on the decision-making process?

a. (Question for clarification; Can you tell about your influence on the decision-making process?)

b. (Question for clarification; How were your interests taken into account?)

c. (Question for clarification; Was there room for other views?)

16. What do you think is an effective way to get involved in the decision-making process/to participate in the decision-making process?

17. How do you want to be involved in a decision-making process?

a. (Question for clarification; Which way of involvement/participation do you prefer?)

18. Which factors are important to you in the decision-making process to feel that a decision has been made in a sound/fair way?

\section{Appendix B}

List of Codes and Categories

\begin{tabular}{|c|c|}
\hline Categories & Codes \\
\hline \multirow{5}{*}{ Mode of participation } & - $\quad$ Private approach \\
\hline & - $\quad$ Cooperative approach \\
\hline & - $\quad$ Phase of involvement \\
\hline & $\begin{array}{l}\text { - Influence (Opinion asked/Opinion taken } \\
\text { into account) }\end{array}$ \\
\hline & - $\quad$ Policy options \\
\hline \multirow{7}{*}{ Modes of distribution } & - $\quad$ Private approach \\
\hline & - $\quad$ Cooperative approach \\
\hline & - $\quad$ Individual compensation (Ground \\
\hline & compensation + Individual \\
\hline & resident compensation) \\
\hline & Community benefits \\
\hline & - $\quad$ Investment and yield \\
\hline
\end{tabular}




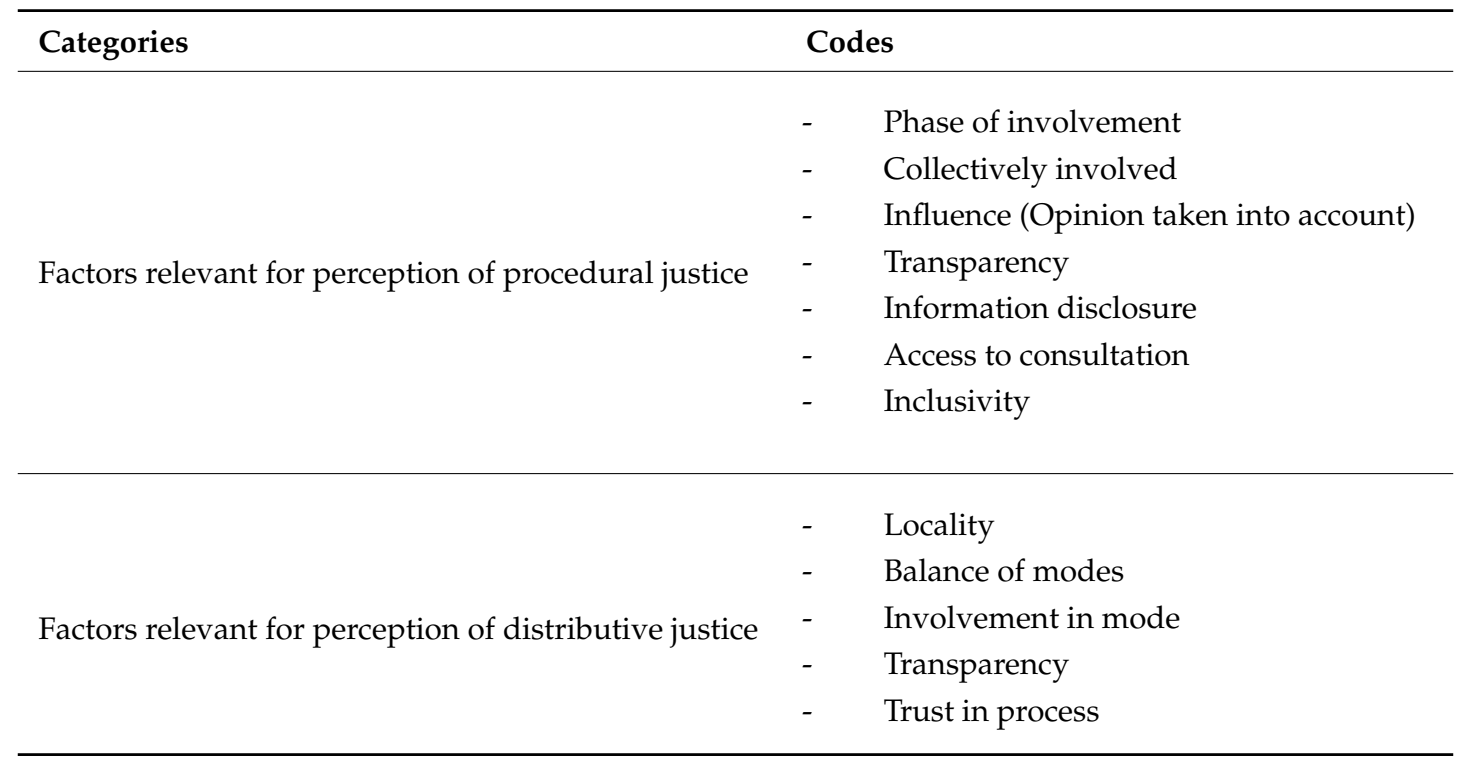

\section{References}

1. Planbureau Voor de Leefomgeving. Analyse van Het Voorstel Voor Hoofdlijnen van Het KlimaatakkoordHoofdstuk 14 Elektriciteit. 2018. Available online: https:/www.klimaatakkoord.nl/documenten/rapporten/ 2018/09/28/pbl-analyse-elektriciteit (accessed on 10 April 2019).

2. Rijksoverheid. Wind op Land; Europees Beleid. Available online: https://www.windenergie.nl/beleid-enregels/europees-beleid (accessed on 24 May 2019).

3. Provinciale Staten Limburg. Voor de Kwaliteit van Limburg; Provinciaal Omgevingsplan Limburg (POL2014). 2014. Available online: https://www.limburg.nl/onderwerpen/omgeving/omgevingsvisie/provinciaal/pol2014-inclusief/ (accessed on 7 July 2019).

4. Provincie Limburg (n.d.). Windenergie. Available online: https://www.limburg.nl/onderwerpen/duurzameenergie/windenergie/ (accessed on 5 April 2019).

5. Regionale Energie Strategie. Noord en Midden- Limburg. 2019. Available online: https://www.regionaleenergiestrategie.nl/kaart+doorklik/noord-+en+midden+limburg/default.aspx (accessed on 13 April 2019).

6. Regionale Energie Strategie. Zuid- Limburg. 2019. Available online: https://www.regionale-energiestrategie. nl/kaart+doorklik/zuid+limburg/default.aspx (accessed on 13 April 2019).

7. Zuidelijke Rekenkamer. Energie in Transitie: Een Vergelijkend Onderzoek Naar de Inzet van de Provincies in de Energietransitie. 2018. Available online: https://www.zuidelijkerekenkamer.nl/wp-content/uploads/ 2018/03/Bijlage-1-Eindrapport-Energie-in-Transitie.pdf (accessed on 5 April 2019).

8. Gemeentegrensoverschrijdende Ontwikkeling Windpark Greenport Venlo in Venlo en Horst aan de Maas. 2018. Available online: https://www.venlo.nl/venlo-windpark-greenport (accessed on 13 June 2019).

9. Devine-Wright, P. Beyond NIMBY-ism: Towards an integrated framework for understanding public perceptions of wind energy. Wind Energy 2005, 8, 125-139. [CrossRef]

10. Lienhoop, N. Acceptance of wind energy and the role of financial and procedural participation: An investigation with focus groups and choice experiments. Energy Policy 2018, 118, 97-105. [CrossRef]

11. Olsen, B.E. Renewable energy: Public acceptance and citizens' financial participation. In Elgar Encyclopedia of Environmental Law; Edward Elgar Publishing Limited: Dortmund, UK, 2016; pp. 476-486.

12. Mundaca, L.; Busch, H.; Schwer, S. 'Successful'low-carbon energy transitions at the community level? An energy justice perspective. Appl. Energy 2018, 218, 292-303. [CrossRef]

13. Langer, K.; Decker, T.; Menrad, K. Public participation in wind energy projects located in Germany: Which form of participation is the key to acceptance? Renew. Energy 2017, 112, 63-73. [CrossRef]

14. Pauw, R. Enthousiasme en Ongenoegen Over Limburgse Windmolens. NOS, 13 March 2019. Available online: https://nos.nl/artikel/2275750-enthousiasme-en-ongenoegen-over-limburgse-windmolens.html (accessed on 21 July 2019). 
15. Reijn, G. 'Niemand wil zo'n Molen in Zijn Achtertuin. Maar als er Iets Tegenover Staat, is Het een Ander Verhaal'. Volkskrant, 13 August 2018. Available online: https://www.volkskrant.nl/economie/niemandwil-zo-n-molen-in-zijn-achtertuin-maar-als-er-iets-tegenover-staat-is-het-een-ander-verhaal \{\{bbc2fd7ad/ (accessed on 23 June 2019).

16. Boon, F.P.; Dieperink, C. Local civil society based renewable energy organisations in the Netherlands: Exploring the factors that stimulate their emergence and development. Energy Policy 2014, 69, 297-307. [CrossRef]

17. Etriplus. Windpark Greenport Venlo. Available online: http://www.etriplus.nl/wind/ (accessed on 6 April 2019).

18. Gemeente Leudal. Windenergie. Available online: https://www.leudal.nl/windenergie (accessed on 12 April 2019).

19. Holsgens, J. Werken Aan Het Draagvlak Voor een Windpark in Heibloem. Leudal Nieuws. 5 March 2018. Available online: https:/leudal.nieuws.nl/2018/03/05/werken-aan-draagvlak-windpark-heibloem/ (accessed on 26 July 2019).

20. Arnstein, S.R. A ladder of citizen participation. J. Am. Inst. Plan. 1969, 35, 216-224. [CrossRef]

21. Musall, F.D.; Kuik, O. Local acceptance of renewable energy-A case study from southeast Germany. Energy Policy 2011, 39, 3252-3260. [CrossRef]

22. Williams, S.; Doyon, A. Justice in energy transitions. Environ. Innov. Soc. Trans. 2019, 31, 144-153. [CrossRef]

23. McCauley, D.; Ramasar, V.; Heffron, R.J.; Sovacool, B.K.; Mebratu, D.; Mundaca, L. Energy justice in the transition to low carbon energy systems: Exploring key themes in interdisciplinary research. Appl. Energy 2019, 233, 916-921. [CrossRef]

24. Murphy, K. The social pillar of sustainable development: A literature review and framework for policy analysis. Sustain. Sci. Pract. Policy 2012, 8, 15-29. [CrossRef]

25. García, J.H.; Cherry, T.L.; Kallbekken, S.; Torvanger, A. Willingness to accept local wind energy development: Does the compensation mechanism matter? Energy Policy 2016, 99, 165-173. [CrossRef]

26. Jenkins, K.; McCauley, D.; Heffron, R.; Stephan, H.; Rehner, R. Energy justice: A conceptual review. Energy Res. Soc. Sci. 2016, 11, 174-182. [CrossRef]

27. Frankena, W.K. The concept of social justice. In Justice in General; Vallentyne, P., Ed.; Routledge: New York, NY, USA, 2003; pp. 63-83.

28. Rawls, J. A Theory of Justice, Rev. ed.; Oxford University Press: Oxford, UK, 1999.

29. Sovacool, B.K.; Dworkin, M.H. Energy justice: Conceptual insights and practical applications. Appl. Energy 2015, 142, 435-444. [CrossRef]

30. Langer, K.; Decker, T.; Roosen, J.; Menrad, K. Factors influencing citizens' acceptance and non-acceptance of wind energy in Germany. J. Clean. Prod. 2018, 175, 133-144. [CrossRef]

31. Rosenthal, M. Qualitative research methods: Why, when, and how to conduct interviews and focus groups in pharmacy research. Curr. Pharm. Teach. Learn. 2016, 8, 509-516. [CrossRef]

32. Reed, M.S.; Graves, A.; Dandy, N.; Posthumus, H.; Hubacek, K.; Morris, J.; Stringer, L.C. Who's in and why? A typology of stakeholder analysis methods for natural resource management. J. Environ. Manag. 2009, 90, 1933-1949. [CrossRef] [PubMed]

(C) 2019 by the authors. Licensee MDPI, Basel, Switzerland. This article is an open access article distributed under the terms and conditions of the Creative Commons Attribution (CC BY) license (http://creativecommons.org/licenses/by/4.0/). 